\title{
KEMAMPUAN PEMECAHAN MASALAH MATEMATIS PESERTA DIDIK BERDASARKAN ADVERSITY QUOTIENT
}

\author{
Niken Septianingtyas ${ }^{1}$, Hella Jusra ${ }^{2}$ \\ ${ }^{1,2}$ Universitas Muhammadiyah Prof. DR. HAMKA \\ hella.jusra@uhamka.ac.id
}

\begin{abstract}
The purpose of this study is to analyze students' mathematical problem solving abilities based on Adversity Quotient (AQ) by knowing the relationship between students' mathematical problem solving abilities with AQ, as well as describing students' mathematical problem solving abilities according to their level of AQ. AQ is an assessment that measures how a person's response in dealing with problems to be empowered into opportunities. AQ is experienced by all groups including students therefore it is necessary to conduct an in-depth study related to the relationship between AQ with students'mathematical problem solving abilities. This type of research is quantitative research. The sample amounted to 132 grade XI science students of senior high school in Jakarta. The instrument used in the form of tests of mathematical problem solving abilities and non-tests in the form of an AQ questionnaire. The results of this study are 1.5\% of students have AQ type climbers, $41.7 \%$ of students have AQ type transition climbers-campers, and $56.8 \%$ of students have AQ type campers, and there is a significant relationship between the ability of solving mathematical problems and adversity quotient. The conclusion of this study is that students with AQ type climbers that have the nature to never give up, AQ type students transition type climbers-campers have both the nature of the nature of climbers and campers, and AQ type campers students have the nature to give up easily and feel satisfied.
\end{abstract}

Keywords: Mathematical Problem Solving Ability, Adversity Quotient.

\begin{abstract}
Abstrak
Tujuan dari penelitian ini yaitu menganalisis kemampuan pemecahan masalah matematis peserta didik berdasarkan Adversity Quotient (AQ) dengan mengetahui hubungan antara kemampuan pemecahan masalah matematis peserta didik dengan AQ, serta mendeskripsikan kemampuan pemecahan masalah matematis peserta didik sesuai dengan tingkatan $A Q$ yang dimilikinya. $A Q$ adalah suatu penilaian yang mengukur bagaimana respon seseorang dalam menghadapi masalah untuk dapat diberdayakan menjadi peluang. Adversity Quotient (ketahanmalangan) dialami oleh semua golongan termasuk peserta didik, maka dari itu perlu dilakukan kajian mendalam terkait hubungan antara $A Q$ dengan kemampuan pemecahan masalah matematis peserta didik. Jenis penelitian ini adalah penelitian kuantitatif. Sampel dalam penelitian ini berjumlah 132 peserta didik kelas XI IPA SMA Negeri di Jakarta. Instrumen yang digunakan berupa tes kemampuan pemecahan masalah matematis dan non tes berupa angket $A Q$. Hasil dari penelitian ini adalah 1,5\% peserta didik memiliki AQ tipe climbers, 41,7\% peserta didik memiliki AQ tipe peralihan climbers-campers, dan 56,8\% peserta didik memiliki AQ tipe campers, serta terdapat hubungan yang signifikan antara kemampuan pemecahan masalah matematis dan $A Q$. Kesimpulan penelitian ini adalah peserta didik dengan AQ tipe climbers yaitu memiliki sifat untuk pantang menyerah, peserta didik AQ tipe peralihan climbers- campers memiliki sifat keduanya yaitu sifat climbers dan campers, dan peserta didik AQ tipe campers memiliki sifat mudah menyerah dan merasa puas.
\end{abstract}

Kata kunci: Kemampuan Pemecahan Masalah Matematis, Adversity Quotient.

\section{PENDAHULUAN}

Pada abad ke-21, pendidikan menjadi faktor utama yang harus diperhatikan dalam upaya meningkatkan sumber daya manusia (SDM). Sumber daya manusia merupakan kekuatan terbesar dalam pengolahan seluruh sumber daya yang ada di sekolah. Sumber daya yang ada di sekolah harus dikelola dengan benar untuk mewujudkan tujuan pendidikan nasional (Rokhmaniyah, 2017). Dengan adanya pendidikan yang berkualitas dapat menciptakan generasi-generasi cerdas, produktif, unggul serta bertanggung jawab yang berguna bagi kemajuan pembangunan bangsa dan negara (Ariawan \& Nufus, 2017). Kualitas pendidikan semakin meningkat hal ini dibuktikan dengan adanya inovasi, 
termasuk dalam sistem pendidikan, kurikulum, metode pembelajaran, dan meningkatnya kualitas guru sebagai intruktur. Terbukti dalam kurikulum pendidikan di Singapura. Kurikulum pendidikan di Singapura berinovasi dengan mengklaim bahwa kemampuan pemecahan masalah adalah tujuan utama pengembangan kurikulum yang bergantung pada lima komponen yang saling terkait, yaitu konsep, keterampilan, proses, sikap, serta metakognisi dan pemecahan masalah sebagai pusatnya (Toh et al., 2019). Di Indonesia terdapat kurikulum yang diterapkan saat ini yaitu kurikulum 2013. Dalam praktiknya, kurikulum 2013 diimplementasikan melalui pembelajaran berbasis aktivitas yang berbasis pendekatan ilmiah dan tematik integratif. Melalui pendekatan tersebut diharapkan peserta didik memiliki kompetensi sikap, keterampilan, dan pengetahuan jauh lebih baik. Peserta didik menjadi lebih kreatif, inovatif, dan lebih produktif sehingga nantinya bisa sukses menghadapi berbagai persoalan dan tantangan di zamannya, memasuki masa depan yang lebih baik (Nurdyansyah \& Fahyuni., 2016). Salah satu karakteristik kurikulum 2013 adalah berpusat pada peserta didik, artinya peserta didik dilibatkan secara aktif, maka dari itu peserta didik sebagai sumber daya manusia di bidang pendidikan perlu dibekali dengan berbagai kemampuan, yaitu kemampuan pemecahan masalah, berpikir logis, analitis, sistematis, kritis, dan kreatif, sehingga peserta didik tersebut menjadi tangguh yang dapat bertahan hidup dalam menghadapi hidup kondisi kompetitif. Salah satu dari kemampuan-kemampuan tersebut yang harus dikembangkan adalah kemampuan pemecahan masalah. Pemecahan masalah adalah dasar dari semua matematika dan proses menemukan pengetahuan baru (Peranginangin et al., 2019). Sehingga pemecahan masalah dapat dikatakan sebagai jantungnya matematika. Matematika juga merupakan komponen penting dari kurikulum sekolah, karena memberikan keterampilan yang vital untuk sukses dengan tugas sehari-hari dan di tempat kerja (Kingsdorf \& Krawec, 2014).

Pentingnya kemampuan pemecahan masalah dalam matematika juga ditegaskan melalui National Council of Teachers Mathematics (NCTM) 2000 menyatakan bahwa standar matematika sekolah haruslah meliputi standar isi dan standar proses. Standar proses meliputi pemecahan masalah, penalaran dan pembuktian, keterkaitan, komunikasi, dan representasi (National Council of Teachers of Mathematics, 2000). Kemampuan pemecahan masalah matematis sangat penting bagi peserta didik bukan saja untuk mempermudah peserta didik mempelajari pembelajaran matematika, namun dalam pembelajaran lain dan dalam kehidupan sehari-hari (Novianti et al., 2020). Dalam memecahkan suatu masalah terdapat empat langkah yaitu understanding the problem (memahami masalah), devising a plan (merencanakan penyelesaian), carrying out the plan (menyelesaikan rencana penyelesaian), dan looking back (memeriksa kembali) (Polya, 1957). Pada proses berpikir peserta didik dalam memahami masalah ini peserta didik mengindentifikasi pertanyaan dari soal yang diberikan terlebih dahulu, akan tetapi, peserta didik secara tidak langsung mengidentifikasi faktafakta, setelah itu mengolah informasi yang dibutuhkan untuk menjawab soal-soal yang ada (Putra et al., 2019). Proses berpikir peserta didik ketika mengorganisasi informasi yang ada, kemudian membuat rencana dari permasalahan yang diberikan, dianalisis kebutuhannya dalam memilih strategi, 
serta menerapkan strategi yang diperlukan untuk menemukan solusinya. Dalam menyelesaikan masalah, peserta didik melakukan aktivitas trial and error. Selanjutnya, setelah peserta didik menemukan hasil dari permasalahannya, peserta didik dapat memastikan bahwa jawaban yang didapat sudah benar atau belum dengan memeriksa kembali jawaban terhadap persoalannya. Peserta didik mengidentifikasi kembali kebutuhan, merencanakan solusi perbaikan masalah, menerapkan rencana perbaikan dan mengevaluasi kembali. Permasalahan dalam pembelajaran matematika yang banyak dialami peserta didik adalah mencerna soal yang berbentuk narasi atau cerita karena pada umumnya proses belajar mengajar di kelas pada mata pelajaran matematika diajarkan bagaimana menggunakan rumus yang ada. Secara psikologi pembelajaran matematika terdapat lima pengaplikasian proses pembelajaran menurut Gestalt, salah satunya adalah prinsip ruang hidup (life space) menjelaskan bahwa perilaku individu memiliki keterkaitan dengan lingkungan dimana ia berada. Oleh karena itu, materi yang diajarkan hendaknya memiliki keterkaitan dengan situasi dan kondisi lingkungan kehidupan peserta didik (Amir, Zubaidah \& Dr. Risnawati, 2015). Dengan ini, peserta didik tidak hanya memiliki kecerdasan intelektual melainkan kecerdasan ketika menghadapi kesulitan. Kecerdasan seseorang dalam menghadapi kesulitan yang dikenal dengan nama Adversity Quotient (AQ) (Hidayat, 2017).

Kepercayaan diri yang sering dialami oleh peserta didik menjadi salah satu alasan dasar kesulitan dalam memecahkan masalah matematika. Oleh karena itu, setiap peserta didik mempunyai kepribadian yang unik, maka kemampuan peserta didik dalam menghadapi kesulitan tersebut akan berbeda antara satu dengan yang lainnya. Dari sinilah Adversity Quotient (AQ) dianggap memiliki peran dalam figur peserta didik ketika mengahadapi suatu pemecahan masalah matematika (Mardiyana, Budi Usodo, 2015). Adversity Quotient adalah suatu penilaian yang mengukur bagaimana respon seseorang dalam menghadapi masalah untuk dapat diberdayakan menjadi peluang. Adversity Quotient dapat menjadi indikator seberapa kuatkah seseorang dapat terus bertahan dalam suatu pergumulan, sampai pada akhirnya orang tersebut dapat keluar sebagai pemenang (climbers), mundur ditengah jalan (campers), atau bahkan tidak mau menerima tantangan sedikitpun (quitters) (Stoltz, 2003). Menurut (Amir, Zubaidah \& Dr. Risnawati, 2015) tipe climber yaitu tipe yang memiliki daya juang yang tinggi. Tipe ini tidak sungkan untuk mengeluarkan usaha yang optimal demi menuai hasil yang maksimal. Tipe ini tidak mudah putus asa, walaupun gagal ia akan terus menerus berusaha sampai dia berhasil mencapai titik yang diinginkan. Tipe camper, yaitu tipe seseorang yang cenderung mudah puas. Tipe ini memiliki daya juang yang cenderung rendah karena sangat mudah puas dengan hasil yang didapatnya. Mereka tidak mau bersusah payah dan berjuang lebih keras untuk mendapatkan hasil yang maksimal karena menurutnya hasil yang diperoleh dari sedikit usaha telah cukup olehnya. Tipe quitter yaitu tipe seseorang yang memiliki daya juang yang rendah. Tipe ini sangat mudah menyerah jika usahanya tidak membuahkan hasil seperti yang ia harapkan atau jika usahanya mengalami jalan buntu. Kesimpulan dari penjelasan tersebut, seseorang dengan tipe climber mempunyai kemampuan untuk menghadapi kesulitan yang berat dan terus 
bergerak maju atau dapat dikatakan tipe climber adalah tipe yang pantang menyerah dan menyukai berbagai tantangan. Tipe camper adalah seseorang yang cukup baik ketika menghadapi suatu masalah, tetapi ketika menghadapi suatu masalah yang menurutnya berat, maka seorang camper akan mudah menyerah. Tipe quitter adalah seseorang yang berbeda diantara climber dan camper, seorang quitter ketika dihadapi dengan suatu masalah yang berat akan menghindar dan tidak ingin mencoba karena seorang quitter merasa dirinya tidak mampu untuk menyelesaikan masalah tersebut.

Beberapa penelitian lain terkait Adversity Quotient (AQ) dan kemampuan pemecahan masalah menjelaskan bahwa seseorang dengan tipe camper dan climber dapat mencapai semua indikator pemecahan masalah menurut NCTM (Darojat \& kartono, 2016). Pada penelitian (Afri, 2018) bahwa terdapat hubungan yang positif dan pengaruh yang signifikan antara Adversity Quotient (AQ) dengan kemampuan pemecahan masalah, sehingga apabila semakin tinggi Adversity Quotient (AQ), maka kemampuan pemecahan masalah pada peserta didik juga akan semakin tinggi. Selain itu, menurut (Hakim, 2020) dalam penelitiannya menyimpulkan adanya pengaruh positif AQ terhadap kemampuan pemecahan masalah. Di penelitian-penelitian sebelumnya Adversity Quotient (AQ) dihubungkan dengan psikologi seseorang yang sedang berkarir. Padahal Adversity Quotient (AQ) atau ketahanmalangan seseorang tidak hanya dialami oleh seseorang yang sedang menata karirnya, melainkan terjadi pada semua orang dan semua golongan termasuk kepada peserta didik. Berdasarkan hal tersebut, perlu dilakukan kajian mendalam terkait hubungan antara Adversity Quotient (AQ) dengan kemampuan pemecahan masalah matematika peserta didik. Tujuan dari penelitian ini adalah menganalisis kemampuan pemecahan masalah matematis peserta didik berdasarkan Adversity Quotient (AQ) yaitu ketika menghadapi berbagai kesulitan, salah satunya adalah ketika menghadapi soal matematika di tingkat Sekolah Menengah Atas (SMA) dengan pokok bahasan barisan dan deret.

\section{METODE}

Jenis penelitian ini menggunakan metode penelitian kuantitatif dengan korelasi untuk mencari hubungan kemampuan pemecahan masalah matematis peserta didik terhadap Adversity Quotient (AQ). Populasi dalam penelitian ini adalah peserta didik SMA Negeri di Jakarta. Sampel yang digunakan adalah semua peserta didik kelas XI IPA sebanyak 132 peserta didik yang dipilih secara purposive sampling kemudian dilanjutkan dengan stratified random sampling. Teknik stratified random sampling digunakan untuk mengelompokkan AQ peserta didik berdasarkan kategori climbers, campers, dan quitters, sehingga dipilih satu subjek untuk setiap kelompok. Berikut diberikan alur penelitian yang dilakukan pada Gambar 1. Instrumen utama dalam penelitian ini menggunakan tes dan non tes. Instrumen tes tersebut didasarkan pada penilaian karakteristik yang baik terhadap kemampuan pemecahan masalah matematis peserta didik dan instrumen non tes didasarkan pada penilaian karakteristik yang baik terhadap Adversity Quotient (AQ). 


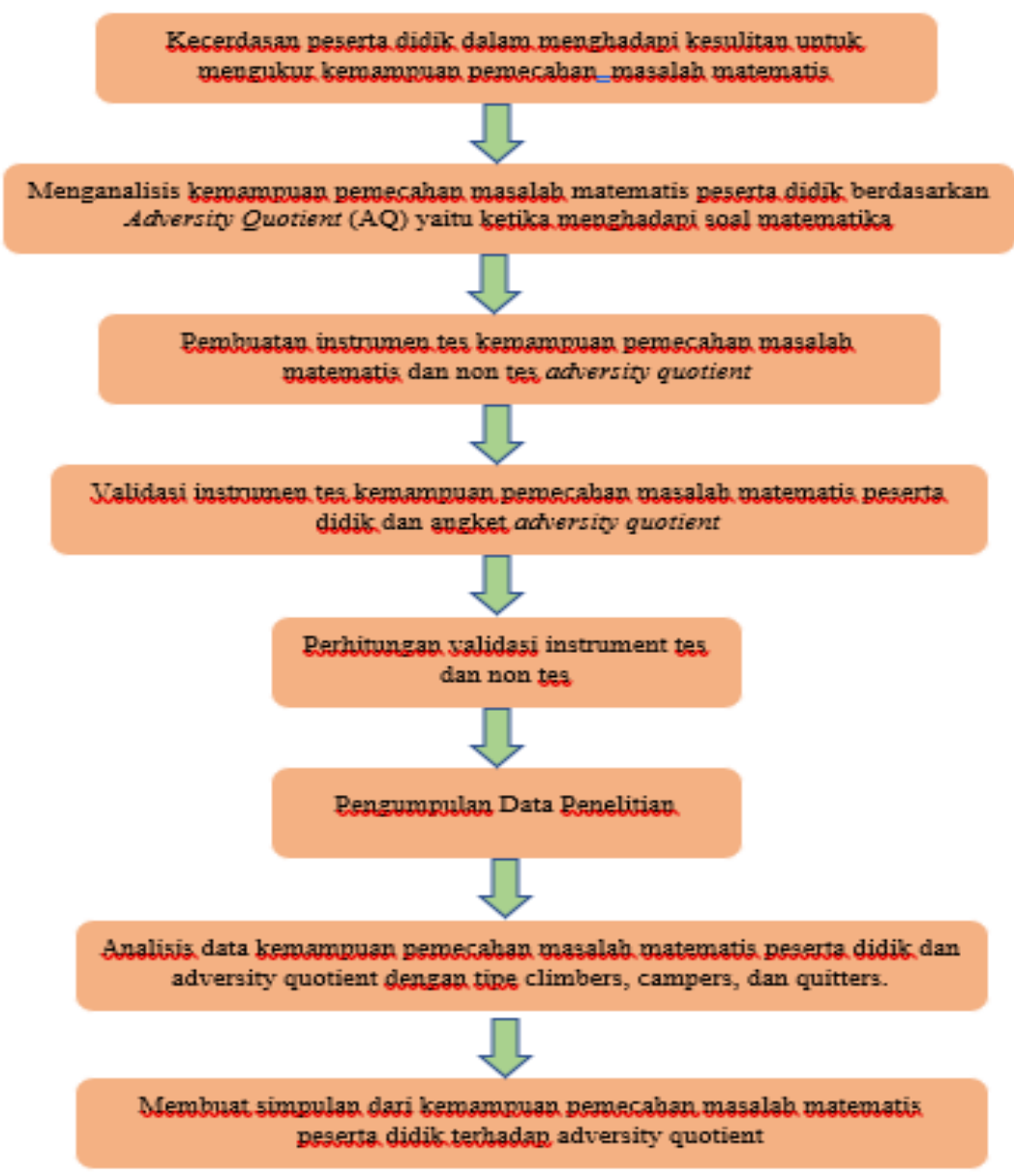

Gambar 1. Alur Penelitian Kemampuan Pemecahan Masalah Matematis terhadap Adversity Quotient $(A Q)$

Instrumen penelitian berupa tes terdiri dari delapan soal berbentuk uraian disusun berdasarkan indikator kemampuan pemecahan masalah matematis. Berikut indikator dari kemampuan pemecahan masalah matematis.

\section{Tabel 1.}

Indikator Kemampuan Pemecahan Masalah Matematis

\begin{tabular}{l|l}
\hline \multicolumn{1}{c|}{ Tahapan } & \multicolumn{1}{c}{ Indikator } \\
\hline $\begin{array}{l}\text { Memahami masalah } \\
\text { (Understanding the } \\
\text { problem) }\end{array}$ & $\begin{array}{l}\text { You have to understand the problem. Such as Draw a figure. } \\
\text { Introduce suitable notation. Separate the various parts of the } \\
\text { condition }\end{array}$ \\
\hline $\begin{array}{l}\text { Merencanakan } \\
\text { Penyelesaian (Devising } \\
\text { a plan) }\end{array}$ & $\begin{array}{l}\text { Find the connection between the data and the unknown. You may be } \\
\text { obliged to consider auxiliary problems if an immediate connection } \\
\text { cannot be found. You should obtain eventually a plan of the } \\
\text { solution. }\end{array}$ \\
\hline $\begin{array}{l}\text { Menyelesaikan } \\
\text { Rencana Penyelesaian } \\
\text { Carrying out the plan) }\end{array}$ & Carrying out your plan of the solution, check each step. \\
\hline $\begin{array}{l}\text { Memeriksa Kembali } \\
\text { (Looking back) }\end{array}$ & Examine the solution obtained. \\
\hline
\end{tabular}

Diadaptasi dari Hidayat (2018) (Hidayat et al., 2018) 
Teknik analisis data yang digunakan adalah analisis data kuantitatif dalam hal ini peneliti mengumpulkan data tes dan non tes yang berkaitan dengan kemampuan pemecahan masalah matematis dalam menyelesaikan soal serta yang berkaitan dengan AQ. Selanjutnya, pada tahap penyajian data peneliti menyusun data yang relevan sehingga menjadi informasi yang dapat disimpulkan dan memiliki makna tertentu. Pada tahap penarikan kesimpulan, peneliti menelaah hubungan antara AQ dan kemampuan pemecahan masalah matematis peserta didik dengan menggunakan aplikasi Statistical Package for Social Science (SPSS) versi 24 yaitu Uji Korelasi dan Uji Regresi linear.

Untuk mengetahui kategorisasi AQ dan kemampuan pemecahan masalah matematis yang dialami peserta didik, peneliti juga menggunakan aplikasi Statistical Package for Social Science (SPSS) versi 24 yaitu dengan Recode Into Different Variables $\rightarrow$ Old and New Values menggunakan acuan kategorisasi AQ menurut Stoltz, sedangkan untuk kemampuan pemecahan masalah matematis dikategorikan dengan frequencies quartiles pada SPSS, sehingga kategorisasi AQ dan kemampuan pemecahan masalah matematis adalah sebagai berikut.

\section{Tabel 2.}

Kategorisasi AQ menurut (Stoltz, 2003)

\begin{tabular}{|c|c|}
\hline Skor & Tipe Adversity Quotient (AQ) \\
\hline $166-200$ & Climbers \\
\hline $135-165$ & Peralihan Climbers-Campers \\
\hline $95-134$ & Campers \\
\hline $60-94$ & Peralihan Campers-Quitters \\
\hline $0-59$ & Quitters \\
\hline
\end{tabular}

Kategori AQ berdasarkan pedoman pengkategorian (Stoltz, 2003), sedangkan tingkat kemampuan siswa pada kategorisasi kemampuan pemecahan masalah matematis (Ninik, dkk, 2016) sebagai berikut .

Tabel 3.

Kategorisasi Tingkat Kemampuan Pemecahan Masalah Matematis

\begin{tabular}{|c|c|}
\hline Kategorisasi & Nilai \\
\hline Rendah & $0 \leq T K S \geq 60$ \\
\hline Sedang & $6<\mathrm{TKS} \leq 75$ \\
\hline Tinggi & $75<T K S \leq 100$ \\
\hline
\end{tabular}

Keterangan:

TKS adalah nilai tingkat kemampuan pemecahan masalah matematis peserta didik.

\section{HASIL}

Sampel dalam penelitian ini dipilih secara purposive sampling, sehingga dilakukan di empat kelas XI IPA, SMA Negeri 54 Jakarta. Jumlah sampel penelitian 132 peserta didik. Sebanyak 132 peserta didik diberikannya instrumen tes dan non tes. Selanjutnya, peserta didik mengerjakan instrumen tes dengan 
pokok bahasan barisan dan deret yang terdiri dari 8 soal berbentuk uraian. Hasil dari pengisian non tes yaitu angket AQ adalah sebagai berikut.

\begin{tabular}{|c|c|c|c|c|c|}
\hline & & Frequency & Percent & Valid Percent & $\begin{array}{c}\text { Cumulative } \\
\text { Percent }\end{array}$ \\
\hline \multirow[t]{4}{*}{ Valid } & climbers & 2 & 1,5 & 1,5 & 1,5 \\
\hline & climbers-campers & 55 & 41,7 & 41,7 & 43,2 \\
\hline & campers & 75 & 56,8 & 56,8 & 100,0 \\
\hline & Total & 132 & 100,0 & 100,0 & \\
\hline
\end{tabular}

Gambar 2. Hasil Adversity Quotient dengan SPSS

Tabel 4.

Hasil Adversity Quotient (AQ)

\begin{tabular}{|c|c|c|c|c|c|}
\hline \multicolumn{7}{|c|}{ Adversity Quotient (AQ) } \\
\hline Tipe & Climbers & $\begin{array}{c}\text { Peralihan } \\
\text { Climbers-Campers }\end{array}$ & Campers & $\begin{array}{c}\text { Peralihan } \\
\text { Campers-Quitters }\end{array}$ & Quitters \\
\hline Skor & $166-200$ & $135-165$ & $95-134$ & $60-94$ & $0-59$ \\
\hline Jumlah Peserta Didik & 2 & 55 & 75 & 0 & 0 \\
\hline
\end{tabular}

Berdasarkan hasil pada Tabel 4. tersebut adalah sebanyak 2 orang peserta didik yang memperoleh skor diantara 166-200 artinya bahwa peserta didik tersebut ketika mengahadapi kesulitan yang berat, maka peserta didik tersebut mempunyai kemampuan untuk terus bergerak maju dengan percaya diri dan pantang menyerah serta menyukai tantangan. Selanjutnya, peserta didik peralihan climbers-campers dengan perolehan skor diantara 135-165 ada sebanyak 55 orang peserta didik artinya peserta didik sudah cukup bertahan menembus tantangan-tantangan dan memanfaatkan sebagian potensi yang dimilikinya. Jumlah peserta didik tipe campers ada sebanyak 75 orang peserta didik yang memperoleh skor diantara 95-134 menunjukkan bahwa peserta didik cukup baik ketika menghadapi kesulitan yang biasa saja, namun ketika menghadapi kesulitan yang besar peserta didik dalam kategori ini mudah menyerah karena merasa puas dengan hasil yang diperolehnya dan tanpa menerima kesulitan yang besar tersebut sebagai tantangan disebut tipe Campers. Lalu, pada peserta didik yang memperoleh skor AQ diantara 60-94 dan 0-59 berjumlah 0 peserta didik artinya pada kategori ini tidak ada peserta didik tipe Quitters. Berdasarkan penjelasan (Amir, Zubaidah \& Dr. Risnawati, 2015) tipe Climbers dan Campers serta pernyataan hasil penelitian ini dapat disimpulkan bahwa rata-rata peserta didik kelas XI IPA di SMA Negeri 54 memperoleh tipe Climbers dan Campers, artinya peserta didik di SMA Negeri kelas XI IPA cenderung mudah menerima berbagai tantangan dan kesulitan, serta cukup baik ketika menghadapi tantangan yang diberikan. 
Instrumen tes dalam penelitian ini dianalisis berdasarkan langkah-langkah pemecahan masalah matematis menurut Polya. Hasil dari instrumen tes tersebut di deskripsikan dengan SPSS, yaitu sebagai berikut.

\begin{tabular}{l|r|r|r|r|r}
\multicolumn{7}{c}{ Descriptive Statistics } \\
& N & Minimum & Maximum & Mean & Std. Deviation \\
\hline $\begin{array}{l}\text { Kemampuan } \\
\text { Pemecahan Masalah }\end{array}$ & 132 & 45 & 128 & 94,73 & 18,775 \\
\hline Valid N (listwise) & 132 & & & & \\
\hline
\end{tabular}

Gambar 3. Hasil Statistik Deskriptif Instrumen Tes Kemampuan Pemecahan Maslaah Matematis Peserta Didik

\begin{tabular}{|c|c|c|}
\hline \multicolumn{3}{|c|}{ One-Sample Kolmogorov-Smirnov Test } \\
\hline & & $\begin{array}{l}\text { Unstandardiz } \\
\text { ed Residual }\end{array}$ \\
\hline \multicolumn{2}{|l|}{ N } & 132 \\
\hline \multirow[t]{2}{*}{ Normal Parameters ${ }^{a, b}$} & Mean &, 0000000 \\
\hline & Std. Deviation & 14,38071931 \\
\hline \multirow[t]{3}{*}{ Most Extreme Differences } & Absolute &, 156 \\
\hline & Positive &, 077 \\
\hline & Negative &,- 156 \\
\hline \multicolumn{2}{|l|}{ Test Statistic } & 156 \\
\hline \multicolumn{2}{|l|}{ Asymp. Sig. (2-tailed) } &, $000^{c}$ \\
\hline
\end{tabular}

Gambar 4. Hasil Uji Normalitas Data

Dari hasil uji normalitas pada Gambar 4. menjelaskan bahwa nilai Asymp. Sig. (2-tailed) sebesar 0 lebih kecil dari 0,05 , artinya data dalam penelitian ini tidak berdistribusi normal. Selanjutnya, peneliti mengkategorikan tingkat kemampuan pemecahan masalah matematis peserta didik. Berikut kategorisasi yang didapat dan hasil dari tes tersebut adalah sebagai berikut.

\begin{tabular}{ll|r|r|r|r} 
& & Frequency & Percent & Valid Percent & $\begin{array}{c}\text { Cumulative } \\
\text { Percent }\end{array}$ \\
\hline \multirow{2}{*}{ Valid } & Tinggi & 79 & 59,8 & 59,8 & 59,8 \\
\cline { 2 - 6 } & Sedang & 32 & 24,2 & 24,2 & 84,1 \\
\cline { 2 - 6 } & Rendah & 21 & 15,9 & 15,9 & 100,0 \\
\cline { 2 - 6 } & Total & 132 & 100,0 & 100,0 & \\
\hline
\end{tabular}

Gambar 6. Pengkategorian Hasil Kemampuan Pemecahan Masalah Matematis Peserta Didik

Pada Gambar 6. didapatkan bahwa 79 peserta didik yang memperoleh skor tertinggi pada kemampuan pemecahan masalah matematis. Pada skor tersebut, terdapat peserta didik yang mempunyai tingkat AQ di tipe climbers, peralihan climbers-campers, dan campers, artinya peserta didik dapat 
memperoleh skor tertinggi terdiri dari tipe Climbers yang mempunyai kemampuan untuk pantang menyerah, menyukai tantangan, ada juga tipe peralihan Climbers-campers yang mempunyai cukup kemampuan untuk menghadapi berbagai kesulitan dengan potensi yang dimilikinya, serta tipe Campers yang mudah menyerah ketika menghadapi permasalahan yang besar. Dikategori perolehan skor sedang dan rendah pada kemampuan pemecahan masalah matematis terdapat 32 orang peserta didik dan 21 orang peserta didik, dimana keduanya terdapat peserta didik yang mempunyai tingkat AQ tipe peralihan climbers-campers dan campers, artinya peserta didik yang memperoleh skor sedang dan rendah tidak memiliki tingkat AQ tipe climbers, dikarenakan pada perolehan skor tersebut ratarata kemampuan peserta didik dalam menghadapi kesulitan cukup baik dan mudah menyerah yaitu tipe Campers. Jadi, dapat disimpulkan bahwa peserta didik yang memperoleh skor tinggi pada kemampuan pemecahan masalah matematis, maka AQ yang dimilikinya juga tinggi disebut tipe Climbers, serta apabila peserta didik memperoleh skor sedang pada kemampuan pemecahan masalah matematis, maka AQ yang dimilikinya sedang disebut tipe Campers.

Asumsi tersebut dapat dibuktikan dengan melakukan uji korelasi dan uji regresi linear menggunakan SPSS. Hasil dari uji korelasi dan uji regresi linear tersebut adalah sebagai berkut.

\begin{tabular}{llr|r} 
& & $\begin{array}{c}\text { Adversity } \\
\text { Quotient }\end{array}$ & $\begin{array}{c}\text { Kemampuan } \\
\text { Pemecahan } \\
\text { Masalah }\end{array}$ \\
\hline Adversity Quotient & Pearson Correlation & 1 &, $197^{*}$ \\
\cline { 2 - 4 } & Sig. (2-tailed) & 132 & 132 \\
\cline { 2 - 4 } & $\mathrm{N}$ &, $197^{*}$ & 1 \\
\hline $\begin{array}{l}\text { Kemampuan } \\
\text { Pemecahan Masalah }\end{array}$ & Pearson Correlation &, 024 & \\
\cline { 2 - 4 } & Sig. (2-tailed) & 132 & 132 \\
\cline { 2 - 4 } & $\mathrm{N}$ & &
\end{tabular}

*. Correlation is significant at the 0.05 level (2-tailed).

Gambar 7. Hasil Uji Korelasi

Berdasarkan Gambar 7. ditunjukkan bahwa nilai $\mathrm{r}$ hitung (Pearson Correlation) pada AQ dan Kemampuan Pemecahan Masalah matematis adalah sebesar 0,197, sedangkan nilai $r$ tabel dengan $\mathrm{df}=130$ adalah sebesar 0,171. Dari penjelasan tersebut didapat bahwa nilai $\mathrm{r}$ hitung $\geq$ nilai $\mathrm{r}$ tabel yaitu $0,197 \geq 0,171$, maka dari itu dapat disimpulkan bahwa ada hubungan antara variabel AQ dan variabel kemampuan pemecahan masalah matematis. Selain itu, nilai dari signifikasi Sig. (2-tailed) sebesar 0,024 dimana nilai signifikasi tersebut lebih kecil dari 0,05 dapat dilambangkan 0,024<0,05 artinya terdapat korelasi yang signifikan antara variabel AQ dan variabel kemampuan pemecahan masalah matematis.

Peneliti menguji data dengan Uji Regresi linear hasilnya sebagai berikut. 


\begin{tabular}{|c|c|c|c|c|}
\hline Model & $R$ & R Square & $\begin{array}{l}\text { Adjusted R } \\
\text { Square }\end{array}$ & $\begin{array}{l}\text { Std. Error of } \\
\text { the Estimate }\end{array}$ \\
\hline 1 & $197^{a}$ &, 039 &, 031 & 14,43592 \\
\hline
\end{tabular}

Gambar 8. Hasil Uji Regresi Linear

Berdasarkan gambar tersebut menunjukkan bahwa nilai $\mathrm{R}$ square sebesar 0,039 artinya bahwa hubungan AQ terhadap kemampuan pemecahan masalah matematis adalah sebesar 3,9\% sedangkan 96,1\% kemampuan pemecahan masalah matematis dihubungkan dengan variabel lain yang tidak diteliti.

Pada penelitian ini, peneliti mengambil sampel secara stratified random sampling dengan mengambil satu subjek berdasarkan tingkatan AQ yaitu Climbers, Campers, dan Quitters. Berdasarkan Gambar 2. menjelaskan bahwa sebanyak 56,8\% peserta didik tipe campers, sisanya sebanyak $41,7 \%$ peserta didik peralihan climbers-campers dan sebanyak $1,5 \%$ peserta didik dengan tipe climbers, artinya peserta didik di SMA Negeri 54 Jakarta dominan memiliki tipe climbers dan campers, tidak ada yang memiliki AQ tipe quitters, maka dari itu peneliti hanya mendeskripsikan sesuai dengan hasil penelitian ini. Hasil penelitian yang akan dideskripsikan adalah bagaimana cara peserta didik menjawab tes kemampuan pemecahan masalah matematis berdasarkan tingkat AQ yang dimiliki peserta didik.

Sesuai dengan tingkat AQ serta kemampuan pemecahan masalah matematis yang dimiliki peserta didik terlihat bahwa proses cara menyelesaikan soal peserta didik dengan tipe climbers dan campers adalah sebagai berikut.

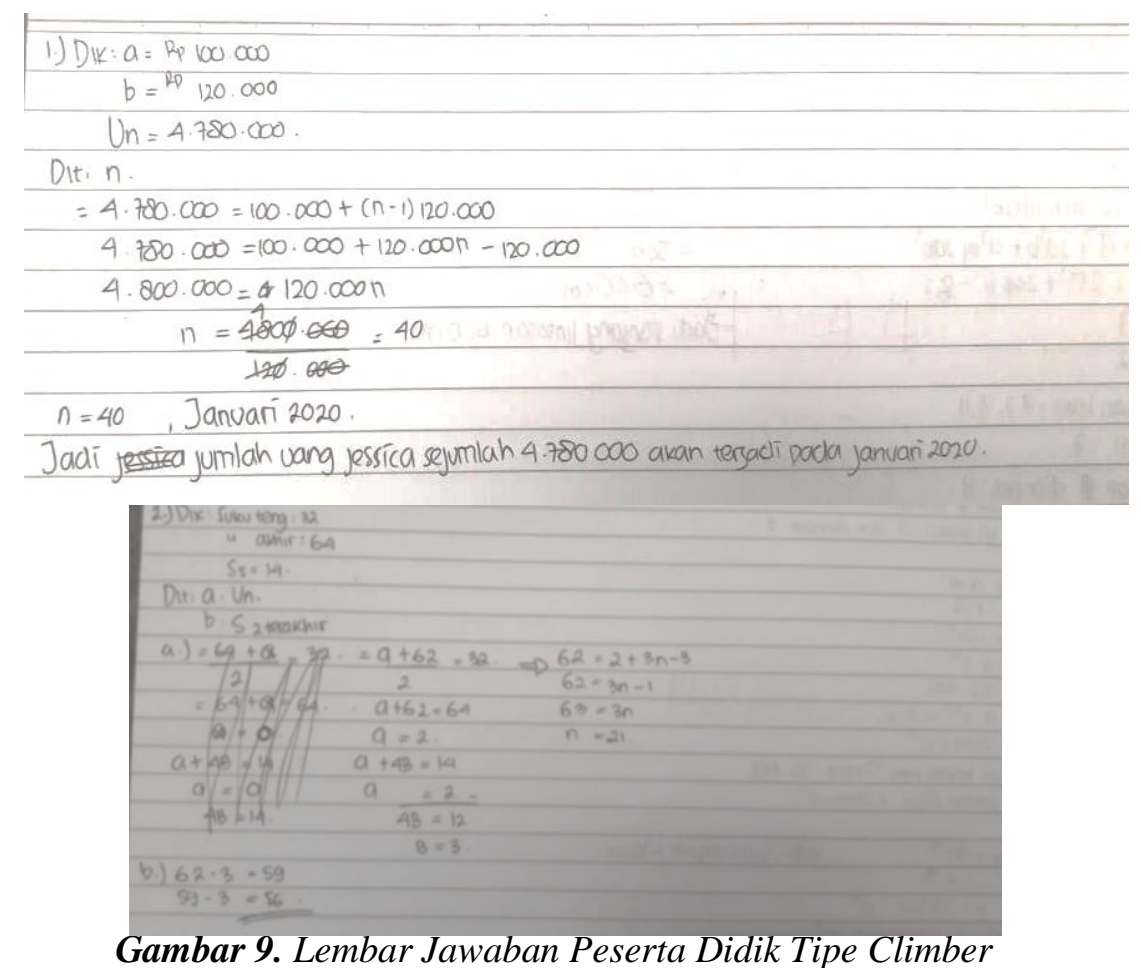


Berdasarkan Gambar 9 dapat dilihat pada lembar jawaban peserta didik mampu menjawab semua soal kemampuan pemecahan masalah matematis. Cara jawab peserta didik yaitu menuliskan apa yang diketahui dan ditanyakan dalam soal untuk membuktikan bahwa dia memahami maksud soal yang diberikan. Ketika merencanakan masalah, peserta didik memiliki rencana yang terpola dan tersusun sehingga pada saat menyelesaikan masalah tersebut menghasilkan jawaban yang benar. Peserta didik saat memeriksa kembali jawabannya juga sangat teliti. Hal ini sesuai dengan penjelasan pada penelitian (Darojat \& kartono, 2016) bahwa pola kemampuan pemecahan masalah matematis peserta didik tipe climber yaitu pada saat memahami masalah peserta didik tipe climber dapat memahami masalah dengan baik, mereka dapat menentukan informasi yang diketahui dan ditanyakan dalam soal dengan baik; mereka dapat menyusun rencana dengan tepat, serta mampu menentukan rumus yang akan digunakan untuk menyelesaikan permasalahan dengan tepat; mampu melaksanakan pemecahan masalah sesuai dengan rencana dan berusaha keras menemukan sebanyak-banyaknya jawaban; dan mampu melakukan pengecekan kembali terhadap jawaban yang diperoleh. Sesuai dengan (Mahareni \& Pradnyo Wijayanti, 2018) bahwa peserta didik dengan tipe climber memiliki sikap pantang menyerah sebelum menemukan penyelesaian, selalu memeriksa kembali terhadap seluruh pekerjaannya menunjukkan bahwa siswa climber mementingkan proses daripada hasil akhir. Maka dapat disimpulkan bahwa peserta didik tipe ini mampu melakukan tahap pemecahan masalah matematis menurut Polya dengan sangat baik, maka dari itu tipe ini memperoleh skor maksimal untuk setiap butir soal kemampuan pemecahan masalah matematis dan memiliki sifat untuk pantang menyerah, serta menyukai tantangan sesuai dengan tingkat AQ yang dimilikinya yaitu tipe Climber.

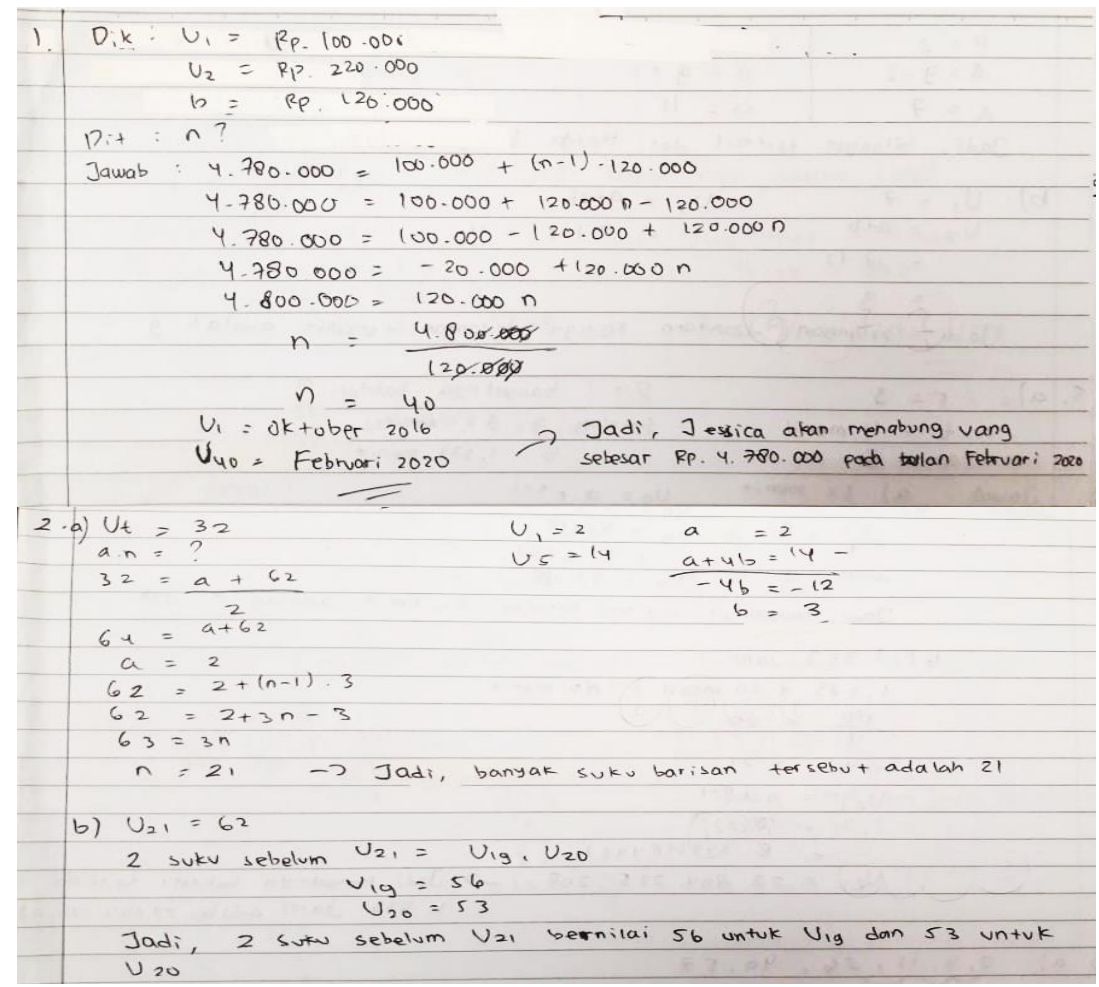

Gambar 10. Lembar Jawaban Peserta Didik Tipe Peralihan Climber-camper 
Pada Gambar 10 terlihat bahwa ketika memahami masalah tipe ini sama seperti tipe climber, yaitu mampu menentukan informasi dari soal kemampuan; mereka merencanakan masalah dengan cukup tepat dan terpola, sehingga mampu menentukan rumus dengan tepat; mampu menyelesaikan masalah sesuai dengan potensi yang dimilikinya, apabila hal tersebut tidak sesuai maka tipe ini akan mudah menyerah; akibat dari tahap menyelesaikan masalah tersebut, tipe ini akan mengabaikan tahap memeriksa kembali hasil dari soal kemampuan tersebut dimana hal ini mengakibatkan skor yang didapat pada tipe ini tidak maksimal seperti halnya dengan tipe climber. Cara jawab peserta didik tipe ini hampir mirip dengan peserta didik tipe climber. Namun, pola kemampuan peserta didik tipe peraliham climber-camper ini sedikit berbeda dengan tipe climber. Perbedaan diantara keduanya adalah tipe climber melaksanakan semua tahap pemecahan masalah matematis menurut Polya dengan sangat baik, sedangkan tipe peralihan climber-camper ini cukup baik melaksanakan tahap pemecahan masalah matematis, artinya terdapat indikator yang tidak dilaksanakan oleh tipe ini. Kesimpulan, peserta didik dengan tipe ini, cukup bertahan dengan memanfaatkan potensi yang dimilikinya, artinya sifat climber yang ada pada tipe ini yaitu mampu bertahan ketika menghadapi suatu masalah, tapi mereka juga akan bertahan jika diiringi dengan potensi yang cukup adalah sifat camper. Hal ini dapat dikatakan bahwa tipe peralihan climber-camper ini memiliki sifat-sifat seperti climber dan camper pada saat-saat tertentu, artinya bisa saja tipe peralihan ini sedikit mudah menyerah dan cemas ketika baru melihat soal yang tidak rutin, ataupun pantang menyerah tetapi tidak maksimal ketika menyelesaikan suatu masalah.

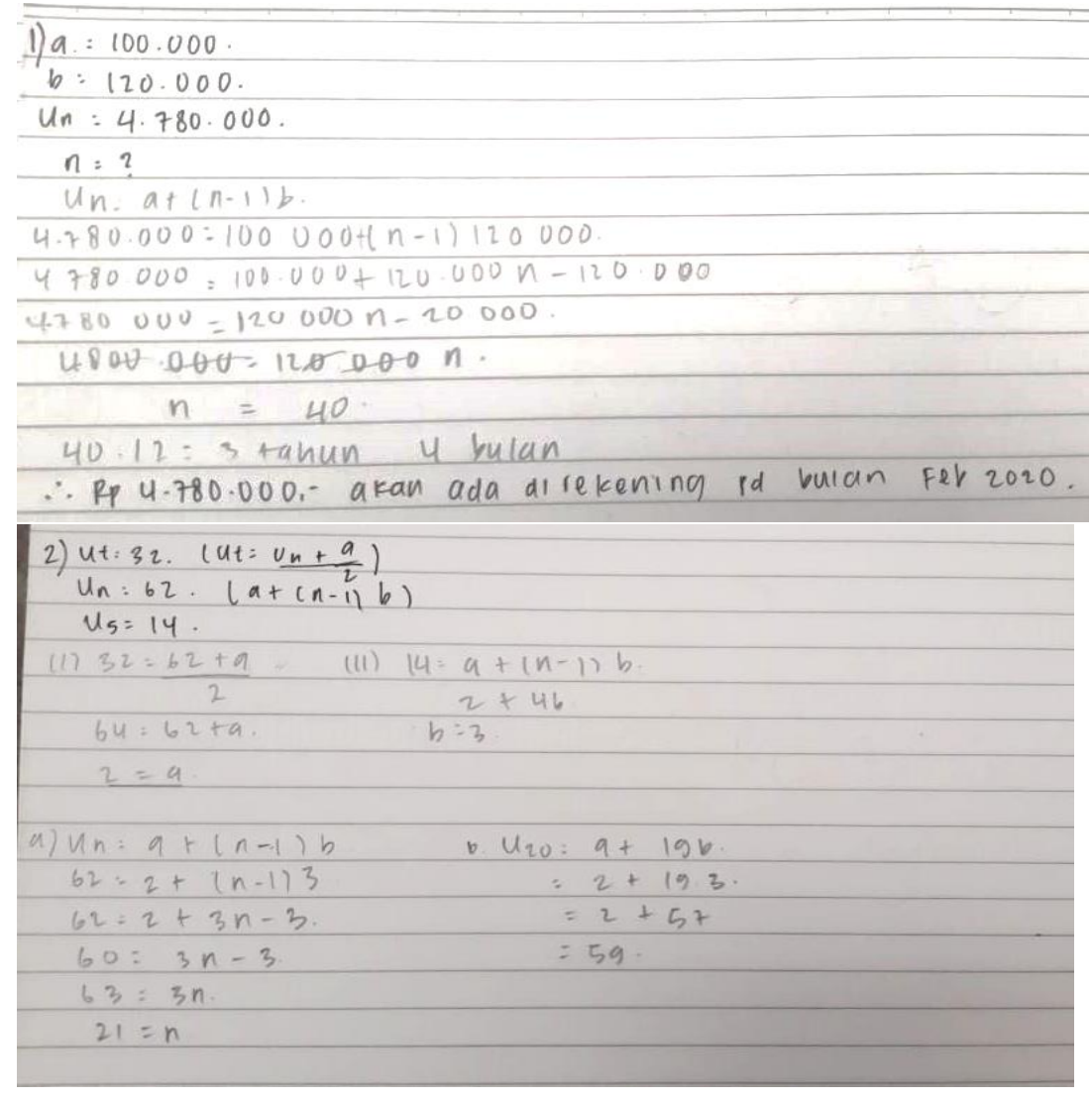

Gambar 11. Lembar Jawaban Peserta Didik Tipe Camper 
Pada Gambar 11. dapat dilihat bahwa pada lembar jawaban peserta didik belum mampu menjawab semua soal kemampuan pemecahan masalah matematis, yaitu hanya $1 / 4$ yang dapat diselesaikan. Cara jawab peserta didik tipe ini belum mampu menginterpretasikan soal kemampuan pemecahan masalah matematis, terlihat pada lembar jawaban, peserta didik tipe ini hanya mampu menuliskan apa yang diketahui. Pada tahap merencanakan masalah, terlihat juga bahwa tipe ini belum direncanakan dengan baik, sehingga pada saat menyelesaikan masalah tidak dilaksanakan dengan sungguh-sungguh. Setelah semua dilaksanakan kurang baik, mereka akan mengumpulkan lembar jawaban dengan cepat apabila benar-benar sudah tidak mampu untuk diselesaikan karena mereka mudah menyerah dan cepat puas, sehingga terlihat bahwa tipe ini tidak melakukan pengecekan jawaban dan mereka mengabaikan tahap memeriksa kembali tahap Polya. Sesuai dengan penelitian (Mahareni \& Pradnyo Wijayanti, 2018), bahwa tipe camper kurang maksimal dalam menyelesaikan suatu permasalahan dan cenderung lebih cepat puas atas hasil yang diperoleh. Peserta didik memiliki kekurangan terhadap langkahlangkah penyelesaiannya, yaitu tidak melakukan pengecekan kembali terhadap semua hasil pekerjaannya sehingga tidak mengetahui adanya kekeliruan dalam perhitungannya. Kesimpulan dari penjelasan diatas, peserta didik dengan tipe camper belum mampu untuk menyelesaikan tahap-tahap soal kemampuan sesuai dengan indikator pemecahan masalah matematis menurut Polya, sehingga terdapat kekeliruan pada jawaban karena tipe ini mudah menyerah. Selain itu, tipe ini juga mudah merasa puas dengan hasil yang diperolehnya tanpa menerima kesulitan yang dihadapinya sebagai tantangan.

\section{KESIMPULAN}

Berdasarkan hasil dan pembahasan, maka dapat disimpulkan bahwa terdapat hubungan yang signifikan antara kemampuan pemecahan masalah matematis dengan adversity quotient sebesar 3,9\% sedangkan 96,1\% kemampuan pemecahan masalah matematis dihubungkan dengan variabel lain yang tidak diteliti. Selanjutnya, sebanyak $1,5 \%$ peserta didik memiliki AQ tipe climbers, sebanyak $41,7 \%$ peserta didik memiliki AQ tipe peralihan climbers-campers, dan sebanyak 56,8\% peserta didik memiliki AQ tipe campers. Pola kemampuan pemecahan masalah matematis peserta didik berdasarkan tingkat AQ yang dimilikinya berbeda. Pada kemampuan pemecahan masalah matematis peserta didik yang memiliki tingkat AQ tipe climbers yaitu mampu melakukan tahap pemecahan masalah matematis menurut Polya dengan sangat baik, maka dari itu tipe ini memperoleh skor maksimal untuk setiap butir soal kemampuan pemecahan masalah matematis dan memiliki sifat untuk pantang menyerah. Kemampuan pemecahan masalah matematis peserta didik dengan AQ tipe peralihan climbers-campers yaitu cukup bertahan dengan memanfaatkan potensi yang dimilikinya, artinya sifat climber yang ada pada tipe ini yaitu mampu bertahan ketika menghadapi suatu masalah, tapi mereka juga akan bertahan jika diiringi dengan potensi yang cukup adalah sifat camper. Hal ini dapat dikatakan bahwa tipe peralihan climber-camper ini memiliki sifat-sifat seperti climber dan 
camper pada saat-saat tertentu. Peserta didik yang mempunyai kemampuan pemecahan masalah matematis dengan AQ tipe campers yaitu belum mampu untuk menyelesaikan tahap-tahap soal kemampuan sesuai dengan indikator pemecahan masalah matematis menurut Polya, sehingga terdapat kekeliruan pada jawaban karena tipe ini mudah menyerah. Selain itu, tipe ini juga mudah merasa puas dengan hasil yang diperolehnya tanpa menerima kesulitan yang dihadapinya sebagai tantangan.

\section{DAFTAR PUSTAKA}

Abdiyani, S. S., Khabibah, S., \& Rahmawati, N. D. (2019). Profil Kemampuan Pemecahan Masalah Matematika Siswa SMP Negeri 1 Jogoroto Berdasarkan Langkah-langkah Polya Ditinjau dari Adversity Quotient. Al-Khwarizmi: Jurnal Pendidikan Matematika Dan Ilmu Pengetahuan Alam, 7(2), 123-134. https://doi.org/10.24256/jpmipa.v7i2.774

Afri, L. D. (2018). HUBUNGAN ADVERSITY QUOTIENT DENGAN KEMAMPUAN PEMECAHAN MASALAH SISWA SMP PADA PEMBELAJARAN MATEMATIKA. AXIOM Jurnal Pendidikan Dan Matematika, VII(2), 47-53.

Amir, Zubaidah, M. P., \& Dr. Risnawati, M. P. (2015). PSIKOLOGI PEMBELAJARAN MATEMATIKA (1st ed.). Aswaja Pressindo.

Ariawan, R., \& Nufus, H. (2017). Hubungan Kemampuan Pemecahan Masalah Matematis dengan Kemampuan Komunikasi Matematis Siswa. Theorems (The Original Research of Mathematics), $1(2), 82-91$.

Bryman, A., \& Cramer, D. (2001). Quantitative Data Analysis SPSS Release 10 For Windows. Routledge.

Darojat, L., \& kartono. (2016). KEMAMPUAN PEMECAHAN MASALAH SISWA DALAM MENYELESAIKAN SOAL OPEN ENDED BERDASARKAN AQ DENGAN LEARNING CYCLE 7E. Unnes Journal of Mathematics Education Research, 5(1), 1-8.

Hakim, F. (2020). Faktor Faktor Adversity Quotient dalam Kemampuan Pemecahan Masalah Pembuktian Matematis Topik Teori Grup. Indonesian Journal of Educational Science (IJES), 2(2), 90-98. https://doi.org/10.31605/ijes.v2i2.663

Hidayat, W. (2017). Adversity Quotient Dan Penalaran Kreatif Matematis Siswa Sma Dalam Pembelajaran Argument Driven Inquiry Pada Materi Turunan Fungsi. KALAMATIKA Jurnal Pendidikan Matematika, 2(1), 15. https://doi.org/10.22236/kalamatika.vol2no1.2017pp15-28

Hidayat, W., Herdiman, I., Aripin, U., Yuliani, A., \& Maya, R. (2018). Adversity Quotient (AQ) dan Penalaran Kreatif Matematis Mahasiswa Calon Guru. Jurnal Elemen, 4(2), 230. 
Kemampuan Pemecahan Masalah Matematis Peserta Didik Berdasarkan Adversity Quotient, Niken Septianingtyas, Hella

https://doi.org/10.29408/jel.v4i2.701

Kingsdorf, S., \& Krawec, J. (2014). Error Analysis of Mathematical Word Problem Solving Across Students with and without Learning Disabilities. 29(2), 66-74.

Mahareni, D. M., \& Pradnyo Wijayanti. (2018). PROFIL SISIWA SMP DALAM MEMECAHKAN SOAL TIMSS DITINJAU DARI TINGKAT ADVERSITY QUOTIENT. Jurnal Ilmiah Pendidikan Matematika, 7(3), 663-668.

Mardiyana, Budi Usodo, N. D. R. (2015). Yang Berkaitan dengan Literasi Matematis ditinjau dari Adversity Quotient ( AQ ). Jurnal Elektronik Pembelajaran Matematika, 3(5), 510.

National Council of Teachers of Mathematics. (2000). Principles and Standards for School Mathematics.

Ninik, Hobri, \& Suharto. (2014). ANALISIS KEMAMPUAN PEMECAHAN MASALAH UNTUK SETIAP TAHAP MODEL POLYA DARI SISWASMK IBU PAKUSARI JURUSAN MULTIMEDIA PADAPOKOK BAHASAN PROGRAM LINIER. KadikmA, [S.1.], v. 5, n. 3, dec. 2014. ISSN 2686-3243.

Noviantii, E., Yuanita, P., \& Maimunah, M. (2020). Pembelajaran Berbasis Masalah dalam Meningkatkan Kemampuan Pemecahan Masalah Matematika. Journal of Education and Learning Mathematics Research (JELMaR), 1(1), 65-73. https://doi.org/10.37303/jelmar.v1i1.12

Nurdyansyah, \& Fahyuni., E. F. (2016). INOVASI MODEL PEMBELAJARAN SESUAI KURIKULUM 2013 (1st ed., p. 11). Nizamia Learning Center.

Peranginangin, S. A., Saragih, S., \& Siagian, P. (2019). Development of Learning Materials through PBL with Karo Culture Context to Improve Students 'Problem Solving Ability and Self-Efficacy. 14(2), 265-274.

Polya, G. (1957). How To Solve It : A New Aspect of Mathematical Method. Princeton University of America.

Putra, Y., Rahmad, S., \& Sudibyo, N. A. (2019). Proses Berpikir Siswa Kelas 12 Sekolah Menengah Kejuruan Dalam Memecahkan Masalah Matematika. 01(05), 53-58.

Rokhmaniyah. (2017). MANAJEMEN SUMBER DAYA MANUSIA UNTUK MENCAPAI PENDIDIKAN YANG BERKUALITAS DI SEKOLAH DASAR Rokhmaniyah. DWIJACENDEKIA Jurnal Riset Pedagogik, 1(1), 73-83. 
Stoltz, P. G. (2003). Adversity Quotient: Mengubah Hambatan Menjadi Peluang (IV). PT Grasindo (Gramedia Widiasarana Indonesia).

Toh, T. L., Chan, C. M. E., Tay, E. G., Leong, Y. H., Quek, K. S., Toh, P. C., Ho, W. K., Dindyal, J., Ho, F. H., \& Dong, F. (2019). Problem Solving in the Singapore School Mathematics Curriculum. 141-164. https://doi.org/10.1007/978-981-13-3573-0_7 